Original scientific paper

Submitted: 2020-05-31

doi:10.5937/nabepo25-26851

Published: 2020-07-17

\title{
THEORETICAL UNDERSTANDINGS OF THE CONCEPT OF A 'PUBLIC SERVANT' TOWARDS A COMMON DEFINITION ${ }^{1}$
}

\author{
Zorica Vukašinović Radojičić ${ }^{2}$ \\ University of Criminal Investigation and Police Studies, Belgrade, Serbia
}

\section{Aleksandra Rabrenović}

The Institute of Comparative Law, Belgrade, Serbia

\begin{abstract}
The public law theorists have been attempting to determine the meaning of the concept of 'public servant' on the basis of various criteria. The existing theoretical views often reflect the dynamics of administrative development of individual countries, which directly affects the status and the role of a public servant. Given the lack of a 'universal definition', the objective of this paper is to point to the diverse theoretical definitions of the notion of the public servants, which are often associated with the role and characteristics of an individual country's public administration, legal tradition, and political and social system. Notwithstanding the existing theoretical differences, the paper also aims to establish the common and essential elements of the concept of a public servant, which transcend the national differences. Although the theoretical concept of the public servants offered by legal science often relies on a definition of positive law, the divergences of scientific opinions keep shaping the normative reality as well.
\end{abstract}

Keywords: public servant, public administration, general interest, theoretical understanding.

1 This paper is the result of the realization of the Scientific Research Project entitled "Development of Institutional Capacities, Standards and Procedures for Fighting Organized Crime and Terrorism in Climate of International Integrations". The Project is financed by the Ministry of Education and Science of the Republic of Serbia (No 179045), and carried out by the Academy of Criminalistic and Police Studies in Belgrade (2011-2020).

2 Corresponding author: zorica.vr@kpu.edu.rs 


\section{INTRODUCTORY REMARKS}

Public servants play a crucial part in carrying out the administrative activities in every country (Stjepanovic, 1958). They have a key role in both formulating and implementing government policies. In addition to this, they have an obligation to devote their entire capacities to their employer for the purpose of achieving public interest and implementing parliamentary decisions in a neutral and equal way, in accordance with principles of loyalty, life-long tenure and a career-based system. As representatives of the state, they are also obliged to be trustworthy and demonstrate decent and respectful behaviour (SIGMA, 2018: 369).

Identifying a 'universal' definition of the public servant across different legal systems, or in the same legal system over different periods of time, appears to be an impossible task. It is difficult to believe that the meaning of this notion can ever be fully agreed upon by all authors. Although defining the concept of a public official has theoretical and practical significance, the existing variations in its interpretation are understandable, as they are based on particularities of the period and the society analysed (Vukašinović Radojičić, 2013:12). For this reason, some administrative law theorists attempted to define the concept of a public official starting from legal, political, and other criteria.

Theoretical considerations of a term public servant are often based on the conceptions of the status and role of public administration in a society. In the model where the public administration is perceived an apparatus of state power, set up with the main goal to 'exercise administrative power', the concept of the public servant is somewhat narrow, as it inclu- des only employees who exercise administrative powers. In the modern public administration systems, however, where the public administration is perceived as an organization with a social function of providing public services to citizens, the concept of a public servant is much broader, as it includes all employees who provide services to the citizens. New public administration systems in modern countries emerge and rest on the modified needs and motivation of citizens as beneficiaries of the public administration services (Kavran, 2003: 23).

Positive legislation in many countries defines a concept of a public servant in a narrow or broader way, depending on the legal status of the officials and the nature of civil servants' employment relationship provided by the law. Henceforth, many authors have started their discussions on a concept of public servants by arguing that a concept of a public official cannot be examined separately from the social environment, and outside the general social context (Kostić, 1933; Krbek, 1948; Stjepanović, 1958). The concept of a public servant, in their view, largely depends on the understanding of the concept of state and public administration, the organization and structure of the administrative system, functions and tasks, decentralization, (de)politicization, legal tradition, political system and social environment. Although many of the legal theorists have tried to identify common values of the concept of a public servant, the discussion on the universal features of this concept has not ended with a tangible result.

Similar to the concept of a civil servant or public administration, the concept of a public servant cannot be fully un- 
derstood just by relying on a positivist approach, i.e. individual countries legal and political context. If we do not find a common theoretical understanding of this concept, the possibility of the use of the term 'public servant' in both theoretical discussions and comparative research will be greatly limited.

The objective of this paper is to analyse the understanding of the concept of a public servant in the domestic and foreign literature and to try to establish its common essential elements. In order to achieve these goals, the authors take into account the following assumptions:

1) Discussions and understandings of the role of the state in a society;

2) Views of public law theorists on what constitutes a concept of a 'public servant';

3) Absence of tendencies to set a 'universal' definition of the concept of public servant;
4) Different notions of public administration in different or the same legal systems;

5) Defining the concept of a public servant depending on legal, political, and social conditions;

6) Theorists' efforts to identify key features (substance) of the public servants' relationship with the state.

Drawing on the above-mentioned objectives and assumptions, the structure of paper shall contain three key parts: 1) the analysis of the current theoretical understanding of the concept of a public of a public servant, 2) an attempt to define universal values of a concept of a public servant, 3) the thoughts and conclusions about the above formulations in aiming to inspire further discussion on the development of this important concept.

\section{DIVERGING VIEWS OF THE CONCEPT OF A PUBLIC SERVANT IN THE CONTEMPORARY LEGAL SCIENCE}

The concept of a public servant emerged with the creation of a modern constitutional monarchy. As Baltić explains, "in the modern state, the official ceases to be a vassal to feudal lords or a personal servant to the absolutist German dukes or the French and English kings, and becomes a public functionary, a servant to many rather than merely to the monarch, a public servant" (Baltić, 139: 8).

Weber was one of the first legal theorists who depicted the concept of a public servant. According to Weber, "administrative apparatus is composed of the officials who are obedient to objective official duties, appointed by strict hierarchy, with strictly set competences in the service, on the basis of professional qualifi- cations that are tested by examinations and confirmed by diplomas, and who receive salary for their work, the level of which depends primarily on the hierarchical rank and responsibility required by the specific position. A typical 'bureaucratic' official is one practicing it as his/her principal vocation" (Weber, 1976: 173-175). Similarly to Weber's understanding, N. Visković refers to public servants as bureaucrats - persons who professionally, permanently under the general norms, discharge administrative functions rather than make political decisions (Visković, 1997:42).

An earlier administrative law theorist, N. Cavallieri also stressed that that the role of the public servant is to serve the 
state in a professional and permanent manner. He held that "an official of the state is anyone who takes on the obligation to put his knowledge and skill to the service of the state with a compensation from the state budget so as to perform the service as a career to which he has permanently committed him/herself" (Cavallieri, 1911: 7). In a similar way, S. Jovanović pointed out that "the official's whole person is preoccupied with public service, he is converted into a body of a foreign state person and working for that person as his main, if not the only calling" (Jovanović, 1922: 422). By analysing the official's role, in his work On the State, in Chapter 62 titled The Officials, Jovanović defines the public servants as persons who are bound by public law contracts to permanently serve the state and who differ from persons bound by private law contracts (Jovanović, 2011: 477).

A. Baltić viewed public servants as persons who 'clearly stand out from all other servants' (Baltić, 1939: 28). He provided a definition of the general notion of public servants from the perspective of substantive law, thus defining the public servants as 'persons who are voluntarily and in a permanent manner (in relative terms) incorporated into permanent and predetermined official posts or official ranks in the permanent public services staff, receiving a salary fixed by law or regulations from the budget' ( $\mathrm{Ibi}$ $\mathrm{dem})$. From this definition the following essential elements of the public servants' employment relationship are derived: public service, voluntary acceptance of service, functions or ranks, continuity of staff, salary, and other. The idea of staff permanence in public administration is associated with the necessity to incorporate public servants in operation of public administration to enable its continuous and uninterrupted functioning.
The incorporation, of course, does not mean an organic incorporation - the officials are not organically connected with public authorities, they do not form their parts; instead, it relates to their inclusion in the permanent administrative staff, thus simultaneously making them operationally and functionally linked to particular posts, where they regularly and permanently perform a particular function (Baltić, 1961: 57).

L. Kostic departed from the view that a public servant in the broadest sense denotes any person who performs a job for the state, even temporarily (Kostić, 1933: 270). In his opinion, public servants form a category of employees classified under the permanent staff; they are permanent officials or career officials, and "their tenure is permanent and life-long". N. Stjepanović introduced special legal regime as a differentia specifica of the term public servant in comparison to other categories of employees. Stjepanović relied on the definitions laid down in positive law regulations and argues that "a public servant is a person who performs public service tasks in public authorities and independent institutions as his/her regular occupation", whereby by 'public service' he assumes the activity ensuring the performance of functions of general interest to the society and other public functions (Stjepanović, 1958: 316). He also points out that the term 'official, i.e. a person in an official capacity' encompasses both public servants and functionaries, while 'employees' assume persons who carry out the administrative and technical functions that ensure the exercise of public authorities' powers (Stjepanović, 1958:346). P. Dimitrijević defined public servants as persons in an official capacity, who perform tasks and functions of relevant 
administrative bodies on a permanent basis (Dimitrijević, 1983: 174).

Another author drawing on the view that public servants are career servants performing public services as their regular and main occupation is Ivo Krbek, who held that "career public servants are available at all times to provide services of a particular profession, in which they move and relocate" (Krbek, 1948: 30). As I. Krbek pointed out, one should bear in mind that "the real interest of the service has a primacy over the servant's personal interest and that legal order grants certain rights to the officials in order for them to deliver the best possible service" (Ibidem). This author further held that "essential thing to thoroughly define a person in the public service of the state, in the broad sense, is precisely that this person acts on behalf of a particular public authority, that his/her activity is considered to be the activity of the particular public authority" (Krbek, 1948:7).

Other authors use slightly different terminology when defining the persons working in the public interest. R. Marković referred to the definition of 'civil servants' as "persons who perform duties within public administrative authorities as their permanent and regular occupation, as their profession (in contrast to elected and appointed persons)" (Marković, 2002: 171). Z. Tomić defines the term 'administrative officials or administrative staff', as "a plurality of persons who work in public administrative authorities (and in other related authorities and organizations), including the heads of those authorities" (Tomić, 2009: 157). E. Pusić held that political functionaries could also be professionals, but only as politicians rather than experts for the administrative organizations in which they discharge their political functions (Pusić, 2002: 205).

Due to the drawbacks of the organizational and functional approach, which are usually used to define the concept of a public administration and subsequently the public servants, a method being increasingly used to define the concept of a public official is one of 'combination', which starts from the form of organization - of the bodies and organizations in which the officials work and the functions - the affairs of public importance. Thus, for example, E. Pusić held that identifying the public administration with the exercise of power makes a public servant "a holder of a portion of the state's monopoly of coercion, or a holder of authorities that derive directly from this monopoly" (Pusić, 1973:176). In attempting to define this concept, taking into account functional and organizational criteria, this author determined the concept of a public servant according to the function he/she discharges and the respective authorities and organizations in which he/she works (Pusić, 1973: 165170). I. Borković viewed a public servant as a person, designated or appointed to a particular post within a public administrative body, who participates in the exercise of public power, in line with his/ her professional qualifications, in a professional manner as his/her permanent occupation (Borković, 1999: 48).

The French administrative science also had an important role to play in defining the concept of a public servant. Given the traditional importance of the provision of public services, public servants in France (fonctionnaires) have always enjoyed a privileged position. In the works of French theorists, the central element of public services provision is acting in a general interest. At the outset 
of the $20^{\text {th }}$ century, the concept of administration changed and expanded, from an organisation which exercises public authority to an organisation which provides public services. The term 'public service' makes its first appearance, to replace the concepts of public authority, sovereignty, state's right to command. General interest has become the central element of a public service. Thus, for example, Laubadere argued that "public service means any activity aimed to satisfy the general interest of the society" (Laubadere, 1953: 40). Duguit has further emphasised, in the spirit of his solidaristic conception of the state and law, that the state and law are not mere instruments in the hands of the ruling class, but an organisation with a goal to pursue the interests of society as a whole. He held that the main task of the state underwent a transformation at the beginning of the 20th century, from the exercise of public authority to the exercise of public services (Duguit, 1929: 3233). In his view, the public servants are those employees who participate in the functioning of the public service (Duguit, 1930: 4).

The French administrative law science further attempted to define the term 'public sector employees' through an assignment of a special legal regime to this category of staff (Nezard, 1901; Bertelemy1930; Plantez, 1991). The status of public servants is subject to public law rules, with civil service disputes falling within the jurisdiction of administrative courts. The French system assigns the attribute 'servant' to those persons who discharge authoritative functions and enforce governmental acts, while being appointed by public law acts (Jeze, 1926: 2). In Jeze's view, any person who even temporarily engages in the exercise of public functions should have the status of a public servant (Jeze, 1930: 241).

Modern German administrative law scientists define the concept of a public servant (Beamte) by analysing the key features of their legal status. Thus, for example, Reichard and Rober claim that typical characteristics of public servants are continuity of employment, right to salary, impartiality, political neutrality, commitment to public service, limited right to strike, and application of special disciplinary rules (Reichard, Rober 2010: 3). The status of public servants is characterised by a long period of preparation and training before entering into employment, public servants tenure, clearly defined career development, appropriate compensation for work and, above all, loyalty and commitment to the public interest (Rabrenović 2011: 240). Given that Germany has a strong tradition of adherence to laws and other regulations ('Rechtsstaat'), some authors stress the dominance of the lawyers' profession in the public service, so-called juristen-monopol (Derlien, Hans-Ulrich 1991: 385). Officials often resist frequent changes and advocate the sustainability of the existing rules and procedures. They are primarily 'in the service' of the state, as opposed to the Anglo-Saxon model where the principle of the New Public Management has prevailed, with the focus on service delivery to customers, efficiency of the administration, and alike.

The British administrative law science also underlies the importance of defining the term public servant. In Wade's opinion, public servants (Public Officers, Public Employees) in Great Britain are "persons who perform governmental functions" and whose status is subject to the public law regime (Wade, 2004: 68). While some authors start from the 
criterion of 'organizational structure and policy implementation' (Fletcher, 1967: 53-54), others regard as the key criterion for defining the concept of public servants the nature of duties that they perform (Dunleavy, 1982: 215; Greenwood, Wilson, 1993: 4). Most theorists point out that the public servants have a duty to assist the Government with integrity, honesty, impartiality, and objectivity, irrespective of the political complexity of formulating policies. Meny and Knapp view the public servants as the subordinates, because they follow and implement political decisions (Meny, Knapp, 1998: 267).

Over the past few decades, the joint OECD and EU programme SIGMA, ${ }^{3}$ has had an important role in defining the concept of a public servant in Europe. In SIGMA's view, public servants are defined as officials exercising managerial, decision-making or implementation functions or entrusted with particularly important tasks within the public administration bodies (SIGMA, 1997).
They need to be subject to a set of special legal conditions, which would enable them to effectively discharge their duties and functions, in a lawful and proper manner (SIGMA 1999: 22). These legal conditions assume "rights and duties, professional stability, protection from political encroachment and from the interference from lobbies, adequate level of salary in order to reduce the likelihood of corruption, disciplinary provisions, and selection based on merit" (SIGMA, 1999). SIGMA especially stresses the importance of merit-based recruitment and promotion, which assumes a selection of the best suitable candidates available for the civil service, and preventing patronage in the staffing of public administration. SIGMA views regarding the human resources management and public service have been further developed in the document "Principles of Public Administration", which currently serve as a basis for assessing the readiness of the EU candidate countries in the EU accession process (SIGMA, 2014).

\section{UNIVERSAL VALUES: KEY FEATURES OF THE CONCEPT OF A PUBLIC SERVANT}

The absence of a universal concept of a public servant necessitates a discussion on the generic features of this notion. Bearing in mind the earlier presented theoretical discussions, the character and structure of public administration, and the nature and importance of functions discharged by public servants, key characteristics of a concept of a public servant, in our view, include the following elements:
1) Acting in public interest. If we approach defining the concept of a public servant from the functional (substantive) aspect, the key criterion is the content of the function he/she discharges, regardless of the organizational form of work. According to the functional criterion, public servants are persons who perform tasks of public importance;

2) Working in the organizational units of public administration - public authori-

3 SIGMA - Support for Improvement in Governance and Management in Central and Eastern European Countries - is a joint initiative of the OECD and the European Union. The initiative supports public administration reform efforts in thirteen countries in transition, and is principally financed by the European Union's Phare Programme. 
ties, non-public entities, and all holders of 'public authorities'. Organizationally, the defining factor of the concept of a public servant is the organisation where a public servant works, i.e. - public administration authorities (Vukašinović Radojičić, 2015: 39). Public servants are hence persons performing duties within public administration authorities and organizations. How wide the notion of the public official will be defined in an individual country will depend on the organization of public administration in that country;

3) Continuity/permanence of employment and professionalism in carrying out their work. Public servants are expected to perform their duties on a permanent basis and as a regular occupation, based on pre-set rights, duties and responsibilities, adhering to the rules of the profession and acting in a politically neutral manner. Given that "the administrative activity of the state can only be efficient when people carrying out those tasks are sufficiently capable, active, loyal, and honest" (Stjepanović, 1958: 315), the feature of permanent and professional discharge of administrative functions is an essential one to the concept of a public servants. Professionalism of public servants is to be secured through several elements: recruitment and selection based on merit, promotion based on performance and competences; providing opportunities for career development; and competitive levels of salary to ensure staff retention and motivation (Rabrenović, 2019: 27). Closely related to the principle of professionalism is the principle of depoliticization of public administration, which assumes establishing mechanisms to prevent political influence on the work of the servants, especially those on higher managerial positions (SIGMA, 2014: 50).
4) Special accountability arrangements for their actions. Public servants enjoy special rights and decision-making powers, which need to be balanced with strengthened accountability for their actions. For this reason, the behaviour of public servants is testable through administrative law either via administrative supervision or through judicial review (e.g. administrative courts). The behaviour of public servants can also be sanctioned via disciplinary law, leading to strong compliancy, procedural focus and an administrative culture with strong emphasis on preventing errors or mistakes (European Commission, 2018: 369);

5) Special legal regime in order to secure public servants professionalism and accountability. The status of public servants is governed by regulations establishing a regime different from the market principles applicable in the private sector, in order to secure the professionalism in their work and accountability for their actions. Regulation by law of the public servants' relationship provides various guarantees, but also establishes their accountability. Despite the popularity of criticising the over-emphasis on laws and rules in contemporary public services and the calls to reduce bureaucracy, rules and administrative burdens, the primacy of law, including the area of the status of public servants, is likely to remain in the future (Demmke, 2010: 9); 6) Changing role throughout time. As we could see from the work of earlier public law theorists, the role of public servants was primarily to comply with the existing rules, regulations and procedures (Weber, 1976: 173-175). This role, however, has been constantly changing, as public servants are faced with more complex tasks, which require flexibility in their work and continuous professi- 
onal development. Public servants are faced with change, often very a rapid one, and need to respond to them in an efficient and effective manner, with the focus on their performance results. At the same time they have to make more autonomous decisions, be more responsible, accountable and acquire new skills and competencies (Demmke, 2010: 9).

Table 1. Key features of a concept of a public servant

\begin{tabular}{|c|c|}
\hline $\begin{array}{c}\text { 1. Acting in a public interest } \\
\text { (functional aspect) }\end{array}$ & $\begin{array}{c}\text { 2. Working in an organisation of } \\
\text { public administration } \\
\text { (organisational aspect) }\end{array}$ \\
\hline $\begin{array}{c}\text { 3. Permanence of employment } \\
\text { and professionalism (merit based } \\
\text { recruitment and selection, career } \\
\text { development, etc.) }\end{array}$ & $\begin{array}{c}\text { 4. Accountability through disciplinary } \\
\text { sanctions and administrative } \\
\text { supervision and judicial review }\end{array}$ \\
\hline $\begin{array}{c}\text { 5. Special legal regime which should ensure professionalism and accountability } \\
\text { 6. Changing role throughout time }\end{array}$ \\
\hline \multicolumn{2}{|c|}{ (from observance of rules and regulations to increased focus on performance) } \\
\hline
\end{tabular}

\section{CONCLUDING REMARKS}

Today, the changing role of the state and public administration requires a flexible concept of a public service and a public servant. Since it is hard to speak of a single definition of the concept of a public servant, we analysed often-conflicting theoretical understandings that can bring us closer to understanding the true essence of this notion.

The definition of the concept of a public servant has often been associated with defining the role that public administration plays in a society. For this reason, in the early works of administrative science, public servants were usually defined as the 'authoritative holders of state power', who committed themselves to the lawful performance of duties, loyalty, and obedience, and stand in a special relationship to the state. Most contemporary authors, however, underlie professionalism and acting in the public interest as key features that define the concept of a public service and a public servant.

The terminology on the use of the concept of 'public servant' is also not uniform. The administrative science defines the general term 'public servant' in a way it corresponds to the positive law systems of many countries. More often than not, the theoretical concept relies on that from positive law, which, likewise, is not uniform in legislative practice. A clear indication of terminological discrepancy can be found in different terms used to depict this concept - administrative officials, administrative workers, administrative staff, civil servants, officials, bureaucrats, and alike.

Although the concept of a public servant does change with time, we have tried to identify the key features that persist and are likely to stick with this concept in the future. As each state needs to ensure 
public service with adequate standards of professionalism, stability, continuity, and accountability of public service, we hope that the identified features will be able to stand the test of time.

At the same time, however, we should be aware that more detailed analysis of the concept of a public servant needs to take into account the broader and individual context of every country - including social, legal, and political aspects. In this sense, our proposed common definition can serve only as a basis for further research and analysis. Each country needs to find its own way in defining the concept of its public servant, in a constant strive towards finding the right balance between competing values and principles: flexibility and the need for stability; autonomy and accountability; individualism and collective action; that will undoubtedly shape the concept of a public servant in diverse directions and individual countries' moulds.

\section{REFERENCES}

Baltić, A. (1961). Osnovni radnog prava Jugoslavije. Beograd: Savremena administracija.

Baltić, A.M. (1939). Opšta teorija o pojmu javnog službenika sa naročitim obzirom na jugoslovensko službeničko zakonodavstvo i krivični zakonik (doktorska disertacija). Beograd: Univerzitet u Beogradu, Pravni fakultet.

Bertelemy, H. (1930). Traité élémentaire de droit administratif. Paris: Rousseau.

Borković, I. (1999). Službeničko pravo. Zagreb: Informator.

Cavallieri, N. (1911). O pravnom odnosu između činovnika i države. Zagreb: Dioničarska tiskara.

Demmke, C. (2010). Civil services in the EU of 27: reform outcomes and the future of the civil service. EIPASCOPE, (2), 5-11. Retrieved May, 5, 2020, from http:// www.oecd-ilibrary.org/governance/promoting-performance-and-professionalism-in-the-public-service_5km 1615rm5mv-en.

Derlien, H.-U. (1991). Historical legacy and recent developments in the German higher civil service. International Review of Administrative Sciences, 57(3), 385-401.

Dimitrijević, P. (1983). Osnovi upravnog prava. Beograd: Pravni fakultet.

Duguit, L. (1930). Traité de droit constitutionnel (3rd ed., Vol. 3). Paris: Fontemoing. Dunleavy, P. (2007). Is there a radical approach to public administration? Public Administration, 60(2), 215-225.

European Comission. (2018). Public administration characteristics and performance in EU28: Germany (VC/2016/0492). Retrieved January, 11, 2020, from http://www. europa.eu.

Fletcher, P. (1967). Public administration. London: London Routledge \& Kegan Paul. Greenwood, J., \& Wilson, D. (1993). Public administration in Britain today. London: Unwin Hyman. 
Jèze, G. (1926). Cours de droit public (No 2). Paris.

Jèze, G. (1930). Les principes généraux du droit administratif(Vol. 2). Paris: M. Giard. Jovanović, S. (2011). O državi: osnovi jedne pravne teorije. Beograd: Univerzitet u Beogradu, Pravni fakultet.

Jovanović, S. (1922). O državi: osnovi jedne pravne teorije (3rd ed.). Beograd: Geca Kon.

Hegel, G.W.F. (1964). Osnovne crte filozofije prava: s Hegelovim vlastoručnim marginama u njegovu priručnom primjerku filozofije prava. Sarajevo: Veselin Masleša.

Kavran, D. (2003). Javna uprava: reforma, trening, efikasnost, Beograd: Savet za državnu upravu.

Kostić, L.M. (1933). Administrativno pravo Kraljevine Jugoslavije (Vol. 1). Beograd: Izdavačka knjižarnica Gece Kona.

Krbek, I. (1948). Lica u državnoj službi. Zagreb: Izdavački zavod Jugoslovenske akademije znanosti i umjetnosti.

Laubadère, A. de (1953). Traité élémentaire de droit administratif (3rd ed.). Paris: Librairie Générale de Droit et de Jurisprudence.

Marković, R. (2002). Upravno pravo: opšti deo (2nd ed.). Beograd: Službeni glasnik.

Meny, Y., \& Knapp, A. (1998). Government and politics in Western Europe: Britain, France, Italy, Germany. New York: Oxford University Press.

Nezard, M. (1901). Théorie juridique de la function publique. Paris: Librairie de la société du recueil général des lois et des arrêts.

Plantez, A. (1991). La Fonction publique: Traité général. Paris: Litec.

Pusić, E. (2002). Nauka o upravi. Zagreb: Školska knjiga.

Pusić, E. (1973). Nauka o uprava (Vol. 1). Zagreb: Školska knjiga.

Rabrenović, A. (2019). Evropski sistemi plata i nagradjivanja državnih službenika. Beograd: Institut za uporedno pravo.

Rabrenović, A. (2011). Osnovni elementi pravnog položaja državnih službenika Savezne Republike Nemačke: Veberova birokratija u novom ruhu? In M. Vasiljević \& V. Čolović (Eds.), Uvod u pravo Nemačke (pp. 224-240). Beograd: Institut za uporedno pravo.

Reichard, C., \& Rober, M. (2010). Inertia of education and recruitment in the German civil service [Paper presentation]. EGPA Annual Conference, Toulouse, September 8-10, 2010.

SIGMA/OECD. (2014). Principles of public administration. Paris: OECD.

SIGMA/OECD. (1999). European principles of public administration (Paper No. 27). Paris: OECD.

SIGMA/OECD. (1997). Promoting performance and professionalism in the public service (Paper No. 21). Paris: OECD. 
Vukašinović Radojičić, Z., Rabrenović, A. (2020). Theoretical understandings

of the concept of a 'public servant'

Stjepanović, N. (1958). Upravno pravo FNRJ: opšti deo. Beograd: Savremena administracija.

Tomić, Z.R. (2009). Opšte upravno pravo (5th ed.). Beograd: Univerzitet u Beogradu, Pravni fakultet.

Veber, M. (1976). Privreda i društvo. Beograd: Prosveta.

Visković, N. (1997). Država i pravo. Zagreb: Birotehnika.

Vukašinović Radojičić, Z. (2015). Pravna pitanja službeničkih odnosa. Beograd: Kriminalističko-policijska akademija.

Vukašinović Radojičić, Z. (2013). Evropski službenički sistemi. Beograd: Kriminalističko-policijska akademija.

Wade, W. (2004). Administrative law. New York: Oxford University Press. 